P ISSN : 2503 - 1708

E ISSN : 2722 - 7340

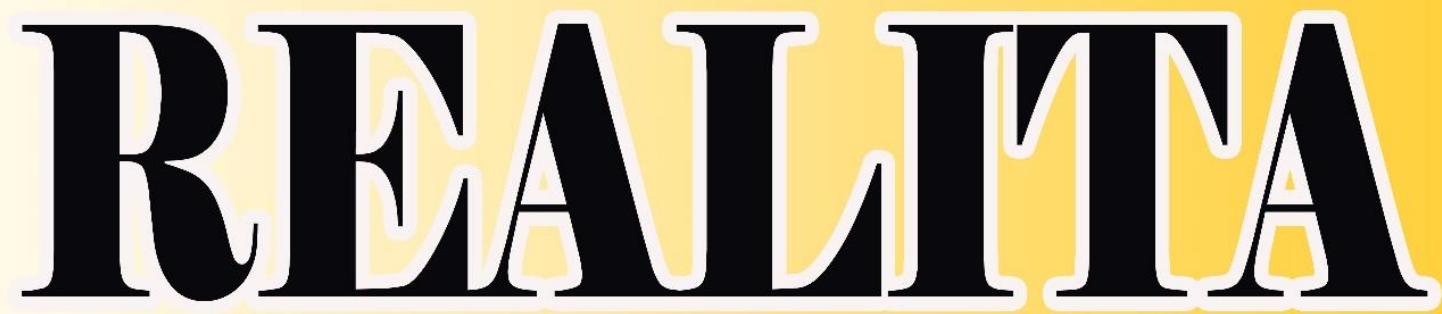

Jurnal Bimbingan dan Konseling

\begin{tabular}{|c|c|c|c|c|c|}
\hline JURNAL & VOLUME & NOMOR & EDISI & HALAMAN & P ISSN : 2503 - 1708 \\
REALITA & 6 & 2 & Oktober 2021 & $1326-1430$ & E ISSN : 2722 - 7340 \\
\hline
\end{tabular}

Diterbitkan oleh:

PROGRAM STUDI BIMBINGAN DAN KONSELING FAKULTAS ILMU PENDIDIKAN DAN PSIKOLOGI UNIVERSITAS PENDIDIKAN MANDALIKA 


\section{REALITA \\ BIMBINGAN DAN KONSELING \\ Jurnal Penelitian dan Pengembangan Pendidikan}

\section{DEWAN REDAKASI \\ Pelindung : Rektor Universitas Pendidikan Mandalika \\ : Dekan FIPP Universitas Pendidikan Mandalika \\ Penanggung \\ Jawab \\ : Kaprodi BK FIPP Universitas Pendidikan Mandalika \\ Editor}

Hariadi Ahmad, M.Pd

Universitas Pendidikan Mandalika

Associate Editor

Mustakim, M.Pd

Universitas Pendidikan Mandalika

Mujiburrahman, M.Pd

Universitas Pendidikan Mandalika

Ahmad Muzanni, M.Pd

Universitas Pendidikan Mandalika

M. Chaerul Anam, M.Pd

Universitas Pendidikan Mandalika

\section{Editorial Board}

Prof. Drs. Kusno, DEA., Ph.D

Universitas Negeri Jember Jawa Timur

Drs. Wayan Tamba, M.Pd

Farida Herna Astuti, M.Pd

Ichwanul Mustakim, M.Pd

Reza Zulaifi, M.Pd

Jessica Festi Maharani, M.Pd

Universitas Pendidikan Mandalika

Universitas Pendidikan Mandalika

Universitas Pendidikan Mandalika

Universitas Pendidikan Mandalika

Universitas Pendidikan Mandalika

\section{Reviwer}

Dr. I Made Sonny Gunawan, S.Pd., M.Pd

Universitas Pendidikan Mandalika

Dr. A. Hari Witono, M.Pd

Universitas Mataram NTB

Prof. Dr. Wayan Maba

Universitas Mahasaraswati Bali

Dr. Gunawan, M.Pd

Universitas Mataram NTB

Dr. Haromain, S.Pd., M.Pd.

Universitas Pendidikan Mandalika

Dr. Hadi Gunawan Sakti, M.Pd

Wiryo Nuryono, M.Pd

Hasrul, S.PdI., M.Pd

Dita Kurnia Sari, M.Pd

Dr. Roro Umy Badriyah. M.Pd., Kons

Universitas Pendidikan Mandalika

Universitas Negeri Surabaya Jawa Timur

STKIP Kie Raha Ternate Maluku Utara

UIN Sunan Ampel Surabaya Jawa Timur

Universitas PGRI Maha Dewa Bali

Ari Khusumadewi, M.Pd

Universitas Negeri Surabaya Jawa Timur 
M. Najamuddin, M.Pd

M. Samsul Hadi, M.Pd

Lalu Jaswandi, M.Pd

Eneng Garnika, M.Pd

Aluh Hartati, M.Pd

Drs. I Made Gunawan, M.Pd

Nuraeni, S.Pd., M.Si

Baiq Sarlita Kartiani, M.Pd

M. Zainuddin, M.Pd

Ahmad Zainul Irfan, M.Pd

Dra. Ni Ketut Alit Suarti, M.Pd

Asep Sahrudin, S.Pd., M.Pd

Suciati Rahayu Widyastuti, S.Pd., M.Pd

Rahmawati M, S.Pd., M.Pd

Ginanjar Nugraheningsih, S.Pd. Jas., M.Or

Dewi Ariani, S.Pd., M.Pd

St. Muriati, S.Pd., M.Pd

Uli Agustina Gultom, S.Pd., M.Pd

Indra Zultiar, S.Pd., M.Pd.
Universitas Pendidikan Mandalika

Universitas Pendidikan Mandalika

Universitas Pendidikan Mandalika

Universitas Pendidikan Mandalika

Universitas Pendidikan Mandalika

Universitas Pendidikan Mandalika

Universitas Pendidikan Mandalika

Universitas Pendidikan Mandalika

Universitas Pendidikan Mandalika

Universitas Pendidikan Mandalika

Universitas Pendidikan Mandalika

Univ. Mathla'ul Anwar Banten

Univ. Nahdlatul Ulama Cirebon

Universitas Muhammadiyah Kendari Sulawesi Tenggara

Universitas Mercu Buana Yogyakarta

Universitas Mahaputra Muhammad Yamin Solok Sumatera Barat

Universitas Bosowa Makassar Sulawesi Selatan

Universitas Borneo Tarakan Kalimantan Utara

Universitas Muhammadiyah Sukabumi Jawa Barat

\section{Alamat Redaksi:}

Redaksi Jurnal Realita Bimbingan dan Konseling (JRbk)

Program Studi Bimbingan dan Konseling

Fakultas Ilmu Pendidikan dan Psikologi Universitas Pendidikan Mandalika

Gedung Dwitiya, Lt. 3 Jalan Pemuda No. 59 A Mataram Telp. (0370) 638991

Email : realita@undikma.ac.id

Web : e-journal.undikma.ac.id

Jurnal Realita Bimbingan dan Konseling menerima naskah tulisan penulis yang original (belum pernah diterbitkan sebelumnya) dalam bentuk soft file, office word document (Email) atau Submission lansung di akun yang diterbitkan setiap bulan April dan Oktober setiap tahun.

Diterbitkan Oleh: Program Studi Bimbingan dan Konseling Fakultas Ilmu Pendidikan dan Psikologi Universitas Pendidikan Mandalika. 


\section{DAFTAR ISI}

Halaman

\section{Nuraeni dan Mastari}

Pengaruh Konseling Kelompok Terhadap Self Esteem Siswa Kelas XI di SMK Negeri 2 Kuripan

\section{Aprilia Yolanda, Ni Ketut Alit Suarti dan Ahmad Muzanni}

Pengaruh Body Shaming Terhadap Kepercayaan Diri Siswa SMA Negeri

1 Batulayar

$1342-1353$

\section{Hariadi Ahmad}

Hubungan Kestabilan Emosi dengan Kontrol Diri Siswa Sekolah Menegah Pertama

\section{Aluh Hartati}

Pengaruh Teknik Modeling Untuk Meningkatkan Empati Siswa

\section{Mustakim}

Pengaruh Teknik Cerita Terhadap Sikap Kemandirian Anak Pada Usia 5-6 Tahun

\section{Farida Herna Astuti dan Ichwanul Mustakim}

Keefektifan Bimbingan Kelompok dengan Teknik Role Playing untuk Meningkatkan Motivasi Belajar

\section{Mujiburrahman dan Soba Al-Qadri}

Hubungan Antara Kemampuan Kontrol Diri Dengan Penyusaian Diri Pada Siswa Kelas XI SMA Negeri 1 Taliwang

\section{Wiwiek Zainar Sri Utami}

Pengaruh Konseling Individu Terhadap Potensi Diri Anak Tunarungu di Sekolah Inklusi

\section{Baiq Nur'aini Cahya Khairani dan Ni Made Sulastri}

Pengaruh Layanan Konseling Humanistik Terhadap Perilaku Agresif pada Siswa Kelas XI IPS-4 di SMA Negeri 7 Mataram

\section{Najamudin}

Pengaruh Teknik Biblioterapi Terhadap Sikap Kemandirian Belajar Pada Siswa VIII SMP Negeri 5 Lembar

\section{Khaerul Huda}

Meningkatkan Pengetahuan dan Pemahaman Perilaku Hidup Bersih dan Sehat dimasa Covid 19 Melalui Metode Demontrasi pada Kelompok B di TK Negeri 01 Wanasaba 


\title{
PENGARUH TEKNIK BIBLIOTERAPI TERHADAP SIKAP KEMANDIRIAN BELAJAR PADA SISWA KELAS VIII SMP NEGERI 5 LEMBAR
}

\author{
Oleh: \\ M. Najamuddin \\ Dosen Program Studi Bimbingan dan Konseling Fakultas Ilmu Pendidikan dan \\ Psikologi Universitas Pendidikan Mandalika Mataram Nusa Tenggara Barat Indonesia \\ Email: najamuddin@undikma.ac.id;
}

\begin{abstract}
Abstrak. Pendidikan mempunyai peran yang sangat penting dalam meningkatkan kualitas sumber daya manusia, sebab melalui pendidikan diharapkan dapat menghasilkan generasi penerus yang berkualitas. Pada saat ini semakin disadari bahwa pendidikan sebagai proses pengubahan sikap dan perilaku seseorang melaui upaya pengajaran dan pelatihan. Pendidikan sangat erat hubungannya dengan mutu siswa, karena siswa merupakan titik pusat proses belajar mengajar. Oleh karena itu perlu diadakan nya teknik biblioterapi, karna salah satu teknik konseling yang memanfaatkan media buku di dalam bacaan untuk membantu dalam mengubah pikiran, perasaan, perilaku dengan menemukan kesenangan dalam membaca dan melepaskan diri dari distress mental sehingga dapat memotivasi siswa agar mampu mengatasi masalah yang dihadapinya. Rumusan masalah dalam penelitian ini adalah "apakah ada Pengaruh Teknik Biblioterapi Terhadap Sikap Kemandirian Belajar Pada Siswa Kelas VIII SMP Negeri 5 Lembar Kabupaten Lombok Barat Tahun Pelajaran 2018/2019?". Tujuan dalam penelitian ini adalah" untuk mengetahui Pengaruh Teknik Biblioterapi Terhadap Sikap Kemandirian Belajar Pada Siswa Kelas VIII SMP Negeri 5 Lembar Kabupaten Lombok Barat Tahun Pelajaran 2018/2019". Populasi dalam penelitian ini 95 siswa, sampel yang digunakan 10 siswa. Dalam penelitian ini metode penggumpulan data yang digunakan adalah metode angket sebagai metode pokok. untuk menganalisa data menggunakan rumus $t$-test. Hasil penelitian yaitu (t-

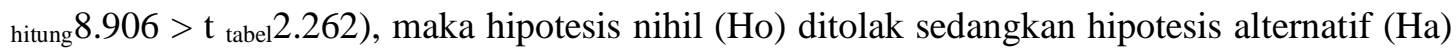
diterima pada taraf signifikansi 5\% sehingga penelitian ini dinyatakan"Signifikan". Maka kesimpulan analisis dalam penelitian ini adalah Ada Pengaruh Teknik Biblioterapi Terhadap Sikap Kemandirian Belajar Pada Siswa Kelas VIII SMP Negeri 5 Lembar.
\end{abstract}

Kata Kunci: Teknik Biblioterapi, Kemandirian Belajar

\section{PENDAHULUAN}

Pada saat ini semakin disadari bahwa pendidikan sebagai proses pengubahan sikap dan perilaku seseorang melaui upaya pengajaran dan pelatihan. Pendidikan sangat erat hubungannya dengan mutu siswa, karena siswa merupakan titik pusat proses belajar mengajar. Oleh karena itu, dalam meningkatkan mutu pendidikan harus diikuti dengan peningkatan mutu siswa. Peningkatan mutu siswa dapat dilihat pada tingginya tingkat prestasi belajar siswa, sedangkan tingginya tingkat prestasi belajar siswa dipengaruhi oleh sikap kemandirian belajar siswa itu sendiri.
Pendidikan mempunyai peran yang sangat penting dalam meningkatkan kualitas sumber daya manusia, sebab melalui pendidikan diharapkan dapat menghasilkan generasi penerus yang berkualitas. Pendidikan merupakan usaha sadar dan terencana untuk dapat mewujudkan suasana belajar dan proses pembelajaran agar peserta didik secara aktif mengembangkan potensi dirinya untuk memiliki kekuatan spiritual keagamaan, pengendalian diri, kepribadian, akhlak mulia, mandiri, serta ketrampilan yang diperlukan dirinya, masyarakat dan bangsa (Undang-undang No 20 Tahun 2003). 
Sikap kemandirian belajar merupakan salah satu unsur yang penting dalam pembelajaran. Sikap kemandirian menekankan pada aktivitas siswa dalam belajar yang penuh tanggung jawab atas keberhasilan dalam belajar. Siswa yang memiliki sikap kemandirian yang kuat tidak akan mudah menyerah. Sikap kemandirian dapat ditunjukkan dengan adanya kemampuan dapat menyelesaikan masalah yang dihadapi dengan tingkah laku. Dengan adanya perubahan tingkah laku maka siswa juga memiliki peningkatan dalam berfikir, menganggap bahwa dalam belajar harus bisa mandiri tanpa mengandalkan bantuan dari orang lain, dan juga tidak menggantungkan belajar dari guru saja, tapi belajar juga bisa dari media cetak, elektronik, alam, atau yang lainnya.

Kepribadian seorang anak yang memiliki ciri kemandirian berpengaruh positif terhadap prestasi belajarnya. Hal ini bisa terjadi karena anak mulai dengan kepercayaan terhadap kemampuannya sendiri secara sadar, teratur dan disiplin berusaha dengan sungguh-sungguh untuk mengejar prestasi belajar, mereka tidak merasa rendah diri dan siap mengatasi masalah yang muncul. Menurut Barnadib (dalam Fatimah, 2010: 142) kemandirian meliputi perilaku mampu berinisiatif, mampu mengatasi hambatan/masalah, mempunyai rasa percaya diri dan dapat melakukan sesuatu sendiri tanpa bantuan orang lain. Di lembaga sekolah, mereka dilatih dan dibina secara mental dan fisik agar menjadi pribadi yang siap berdikari (berdiri di atas kaki sendiri) pada masa depan dan tentunya diimbangi dengan bekal ilmu pengetahuan dan ketrampilan yang dapat diandalkan untuk membuktikan bahwa anak didik tersebut memiliki potensi.

Berdasarkan hasil observasi awal pada tanggal 21 Nopember 2016 bahwa masih banyak siswa yang kurang memiliki sikap kemandirian belajar, sikap kemandirian belajar ini berasal dari siswa itu sendiri dalam mengikuti pembelajaran sedangkan penyebab siswa tidak mandiri dalam belajar, adanya rasa malas, lebih banyak bermain ketimbang membaca yang timbul dalam diri siswa, sarana belajar yang kurang memadai dalam proses belajar dan sikap orang tua yang tidak memberikan perhatian dalam belajar atau pun orang tua terlalu berlebihan perhatiannya.

Sikap kemandirian belajar sangat diperlukan, karena kemandirian merupakan proses menggerakkan kekuatan atau dorongan dari dalam diri individu yang belajar untuk menggerakkan potensi dalam dirinya tanpa ada tekanan atau pengaruh asing dari luar dirinya. Oleh karena itu, konselor punya peran besar dalam miningkatkan sikap kemandirian dalam belajar pada siswa. Dari berbagai teknik yang ada, teknik biblioterapi (trapi bacaan) dipilih peneliti untuk membantu meningkatkan sikap kemandirian belajar siswa. Bibliotherapy sering disebut juga terapi membaca, yang didalam proses seseorang yang mengalami masalah diminta membaca buku-buku yang bersifat membantu dirinya dan memotivasi agar mempercepat penyembuhan. Membaca mengenai kesulitan orang lain yang sama dengan mereka, dapat memberikan kesadaran dan pemahaman terhadap masalah yang dihadapinya. Berdasarkan uraian di atas bahwa banyak siswa yang kurang memiliki sikap kemandirian belajar seperti siswa yang malas dalam mengerjakan tugas, menjawab soal dan menjawab pertanyaan, kurang disiplin belajar, kurang memanfaatkan waktu jam kosong pelajaran untuk belajar sendiri atau mengunjungi perpustakaan untuk membaca.

\section{KAJIAN PUSTAKA}

Kemandirian adalah usaha untuk melepaskan diri dari orang tua dengan maksud untuk menemukan dirinya melalui 
proses mencari identitas ego, yaitu merupakan perkembangan kearah individualitas yang mantap dan berdiri sendiri". Kemandirian biasanya ditandai dengan kemampuan menentukan nasib sendiri, kreatif dan inisiatif, mengatur tingkah laku, bertanggung jawab, mampu menahan diri, membuat keputusankeputusan sendiri serta mampu mengatasi masalah tanpa ada pengaruh dari orang lain. Sedangkan menurut Fatimah (2010) Kemandirian merupakan suatu sikap individu yang diperoleh secara kumulatif selama perkembangan, dan individu akan terus belajar untuk bersikap mandiri dalam menghadapi berbagai situasi di lingkungan, sehingga individu pada akhirnya mampu berpikir dan bertindak sendiri". Dengan kemandiriannya, seseorang dapat memilih jalan hidupnya untuk berkembang dengan lebih mantap.

Slameto (dalam Komsiyah, 2012) "Pengertian belajar dapat didefinisikan sebagai suatu proses usaha yang dilakukan seseorang untuk memperolah perubahan tingkah laku yang baru secara keseluruhan, sebagai hasil pengalamannya sendiri dalam interaksi dengan lingkungannya". Sedangkan menurut Thorndike (dalam Asri, 2012: 21) belajar adalah proses interaksi antara stimulus dan respon. Stimulus yaitu apa saja yang dapat merangsang terjadinya kegiatan belajar seperti pikiran, perasaan. Sedangkan respon yaitu reaksi yang dimunculkan peserta didik ketika belajar, yang juga dapat berupa pikiran, perasaan atau tindakan. Berdasarkan beberapa pengertian di atas dapat disimpulkan bahwa sikap kemandirian belajar merupakan suatu usaha yang dilakukan untuk melakukan aktivitas belajar dengan cara melatih diri sendiri tanpa bergantung pada orang lain untuk memperoleh perubahan tingkah laku yang mempunyai kebebasan dalam membuat keputusan serta mampu bertanggung jawab atas tindakannya, sebagai hasil pengalamannya sendiri dalam interaksi dengan lingkungannya.

Sikap kemandirian belajar adalah merupakan kesiapan dari individu yang mau dan mampu untuk belajar dengan inisiatif sendiri tanpa bantuan orang lain,berkaitan dengan hal tersebut dapat dilihat dari berbagai aspek. Robert (dalam Fatimah, 2010) menambahkan ada empat aspek- aspek kemandirian yaitu: 1) Emosi, 2) Ekonomi, 3) Intelektual, 4) Sosial, adapun penjelasannya sebagai berikut Emosi yaitu aspek ini ditunjukkan dengan kemampuan mengontrol emosi dan tidak tergantungnya kebutuhan emosi dari orang tua, (2) Ekonomi yaitu aspek ini ditunjukkan dengan kemampuan mengatur ekonomi dan tidak tergantungnya kebutuhan ekonomi pada orang tua, (3) Intelektual yaitu aspek ini ditunjukkan dengan kemampuan untuk mengatasi berbagai masalah yang dihadapi, (4) sosial yaitu aspek ini ditunjukkan dengan kemampuan untuk mengadakan interaksi dengan orang lain dan tidak tergantung atau menunggu aksi dari orang lain.Sedangkan Steiberg (dalam Desmita, 2014: 186) aspek-aspek kemandirian ada tiga, yaitu: Kemandirian emosional, yakni aspek kemandirian yang menyatakan perubahan pendekatan hubungan emosional antar individu, seperti hubungan emosional peserta didik dengan guru atau dengan orang tuanya, (2) Kemandirian tingkah laku, yakni suatu kemampuan untuk membuat keputusankeputusan tanpa tergantung pada orang lain dan melakukanya secara bertanggung jawab, (3) Kemandirian nilai, yakni kemampuan memaknai seperangkat prinsip tentang benar salah, tentang apa yang penting dan apa yang tidak penting.

Biblioterapi berasal dari kata biblion dan therapeia. Biblion berarti buku atau bahan bacaan, sementara therapeia artinya penyembuhaan. Jadi, teknik biblioterapi dapat dimaknai sebagai upaya penyembuhan melalui buku. Bahan bacaan 
berfungsi untuk mengalihkan orientasi dan memberikan pandangan-pandangan yang positif sehingga menggugah kesadaran penderita untuk bangkit menata hidupnya. teknik biblioterapi adalah istilah yang dilontarkan oleh Samuel Crothers untuk mendeskripsikan penggunaan buku sebagai bagian dari proses konseling" Jackson (dalam Erford, 2016).

Austin (dalam Apriliawati, 2011) menjelaskan bahwa "teknik biblioterapi untuk anak adalah menggunakan buku sebagai terapi untuk mendukung kebutuhan anak dalam memproses pengalaman pribadi yang sulit seperti pengalaman yang menyakitkan dan membingungkan bagi anak". Sedangkan McArdle \& Byrt (dalam Apriliawati, 2011) menjelaskan bahwa "teknik biblioterapi didefinisikan sebagai terapi menggunakan buku untuk memfasilitasi pengungkapan diri, penerimaan diri dan aktualisasi diri seseorang". Berdasarkan pendapat ahli di atas, maka dapat disimpulkan bahwa teknik biblioterapi adalah salah satu teknik konseling yang memanfaatkan media buku di dalam bacaan untuk membantu dalam mengubah pikiran, perasaan, perilaku dengan menemukan kesenangan dalam membaca dan melepaskan diri dari distress mental sehingga dapat memotivasi siswa agar mampu mengatasi masalah yang dihadapinya.

Teknik Biblioterapi sebagai suatu model pembelajaran untuk membantu siswa menemukan makna diri di dunia sosial. Melalui teknik biblioterapi siswa belajar menggunakan buku untuk mengungkapkan masalah yang ditemukan dalam bahan bacaan. Vernon menjelaskan bahwa tujuan dari teknik biblioterapi yaitu: 1) Mengembangkan rasa yang lebih positif dari diri mereka sendiri, belajar tentang dunia, mengatasi stres, memberikan wawasan terhadap suatu masalah, menegaskan pikiran dan perasaan, merangsang diskusi tentang masalah, 2) Menciptakan kesadaran orang lain yang memiliki masalah yang sama, memberikan solusi untuk masalah, mengkomunikasikan nilai-nilai dan sikap baru, dan menemukan makna dalam kehidupan, 3) Mendorong anak gemar membaca, ketika anak-anak membaca buku cerita, mereka dapat mengaitkan masalah mereka dengan karakter yang ada di buku, dan belajar bahwa mereka tidak sendirian atau orang pertama yang mengalami masalah itu, 4) Mendampingi seseorang yang tengah mengalami emosional yang berkecamuk karena permasalahan yang dihadapi dengan menyediakan bahan- bahan bacaan dengan topik yang tepat dan mengandung nilainilai karakter yang ingin dibangun pada diri individu yang bersangkutan, 5) Menyajikan informasi yang dibutuhkan atau sesuai dengan nilai karakter yang ingin mereka bangun, 6) Membentuk tingkah lakunya secara umum, dengan mêngetahui informasi yang ada dalam bahan bacaan, mereka dapat secara khusus membentuk sikap, persepsi, mengubah prasangka sosial dan perubahan Iainnya, 7) Sebagai stimulasi pikiran yang memungkinkan para anggota dapat menyilangkan gagasan-gagasan sehingga kesadarannya menjadi meningkat.

Sedangkan Vernon (dalam Erford, 2016) menjelaskan bahwa Biblioterapi memiliki lima tujuan antara lain: Mengajarkan berfikir konstruktif dan positif, (2) Mendorong untuk mengungkapkan masalah dengan bebas, (3) Membantu klien dalam menganalisis sikap dan prilakunya, (4) Membantu pencarian solusi-solusi alternative untuk masalah klien, dan (5) Memungkinkan klien untuk menemukan bahwa masalahnya serupa dengan masalah orang lain. Berdasarkan uraian di atas, maka dapat disimpulkan bahwa teknik biblioterapi adalah pembelajaran yang bertujuan untuk membantu siswa untuk mengembangkan rasa yang lebih positif, 
mendorong anak untuk gemar membaca agar mereka dapat mengkaitkan masalah mereka dengan karekter yang ada di buku, mendampingi seseorang yang tengah mengalami emosi karna permasalahan yang dihadapinya dengan menyediakan bahan bacaan yang mengandung nilai-nilai karakter yang ingin dibangun, menyajikan informasi yang dibutuhkan, mengungkapkan masalah yang dihadapinya secara bebas, dan membantu siswa agar mampu menemukan solusi yang dihadapinya di dalam buku bacaan.

Teknik biblioterapi menggunakan bahan bacaan yang mengandung nilai-nilai karakter yang ingin dibangun, menyajikan informasi yang dibutuhkan, mengungkapkan masalah yang dihadapinya, dan membantu siswa agar mampu menemukan solusi yang dihadapinya didalam dalam buku bacaan Purwanto (dalam Emen, 2016: 12) menjelaskan bawha intervensi biblioterapi dapat dikelompokkan dalam empat aspek, yaitu: (1) Aspek intelektual, (2) Aspek sosial, (3) Aspek perilaku individu, dan (4) Aspek emosional. Adapun penjelasannya sebagai berikut: Aspek intelektual, Pada aspek intelektual individu memperoleh pengetahuan tentang perilaku yang dapat memecahkan masalah, membantu pengertian diri, serta mendapatkan wawasan intelektual. Selanjutnya, individu dapat menyadari ada banyak pilihan dalam menangai masalah. (2) Aspek social, Di tingkat sosial, individu dapat mengasah kepekaan sosialnya. Ia dapat melampaui bingkai referensinya sendiri melalui imajinasi orang lain. Teknik ini dapat menguatkan pola-pola sosial, budaya, menyerap nilai kemanusiaan dan saling memiliki. (3 )Aspek perilaku individuPerilaku individu akan mendapatkan kepercayaan diri untuk membicarakan masalah-masalah yang sulit didiskusikan akibat perasaan takut, malu, dan bersalah. Lewat membaca, individu didorong untuk diskusi tanpa rasa malu akibat rahasia pribadinya terbongkar. (4)Aspek emosional Pada tingkat emosional, individu dapat terbawa perasaannya dan mengembangkan kesadaran menyangkut wawasan emosional. Teknik ini dapat menyediakan solusi-solusi terbaik dari rujukan masalah sejenis yang telah dialami orang lain sehingga merangsang kemauan yang kuat pada individu untuk memecahkan masalahnya.

\section{METODE PENELITIAN}

Metode pendekatan atau jenis penelitian ini menggunakan penelitian kuantitatif dengan menggunakan pendekatan eksperiment. Manfaat dari rancangan penelitian adalah untuk menggambarkan skema penelitian.Rangcangan penelitian adalah suatu pendekatan yang digunakan dalam suatu penelitian. Dalam metodelogi penelitian dijelaskan bahwa: "Rancangan pada dasarnya merupakan keseluruhan proses pemikiran dan penentuan matang tentang hal-hal yang dilakukan serta dapat pula dijadikan dasar-dasar penelitian baik oleh peneliti sendiri maupun orang lain terhadap penelitian dan bertujuan memberi pertanggung jawaban terhadap semua langkah yang diambil" (Sugiyono, 2010).

Penelitian ini menggunakan desain penelitian one group pre test dan post test design dimana dalam rancangan ini hanya terdapat satu kelompok subjek yaitu kelompok eksperimen sebagai kelompok yang dikenakan perlakuan (Treatment). Pertama-tama dilakukan pengukuran terhadap kelompok eksperimen, lalu dikenakan perlakuan (Treatment) berupa layanan teknik biblioterapi dalam jangka waktu tertentu, kemudian dilakukan pengukuran untuk kedua kalinya dengan tujuan untuk mengetahui perbedaan hasil pre test sebelum diberikan perlakuan (Treatment) dengan post test setelah diberikan perlakuan (Treatment).

Apabila seseorang akan meneliti semua elemen yang ada dalam wilayah 
penelitian, maka penelitinya merupakan penelitian populasi. Populasi adalah keseluruhan subjek penelitian.Studi atau penelitiannya juga disebut studi sensus. (Suharsimi, 2014), sedangkan menurut peneliti lain populasi adalah wilayah generalisasi yang terdiri atas obyek/subyek yang mempunyai kualitas dan karakteristik tertentu yang ditetapkan oleh peneliti untuk dipelajari dan kemudian ditarik kesimpulannya (Sugiyono, 2016). Berdasarkan pendapat para ahli di atas, maka dapat disimpulkan bahwa populasi adalah keseluruhan obyek yang akan diteliti yang memiliki ciri atau karakteristik bersama yang membedakannya dengan subyek lain. Kaitannya dengan penelitian ini, yang menjadi populasi adalah seluruh siswa Kelas VIII SMP Negeri 5 Lembar Kabupaten Lombok Barat Tahun Pelajaran 2018/2019.

Instrumen merupakan alat yang digunakan untuk memperoleh data tentang objek yang diteliti. Instrument penelitian mencakup unsur-unsur yang dibutuhkan dalam pengumpulan data. Alat yang digunakan untuk memperoleh data dalam mengukur masing-masing variabel penelitian" (IKIP Mataram, 2011: 15). Sedangkan ahli lain menjelaskan "Instrumen penelitian adalah suatu alat yang digunakan untuk mengukur fenomena alam maupun sosial yang diamati" (Sugiyono, 2015). Di dalam pelaksanaan penelitian dimulai dengan menyusun instrument penelitian yaitu alat untuk memperoleh data yang diinginkan. Dalam penelitian ini akan menggunakan angket sebagai instrumen penelitian. Dimana penulis membuat sejumlah pertanyaan yang akan disebarkan kepada semua responden untuk dijawab.

Dalam penelitian ini, instrument yang digunakan adalah berupa angket, yaitu untuk memperoleh data tentang kemamapuan berkomunikasi rendah pada siswa yaitu berupa angket tertulis dalam bentuk tertutup sebagai metode pokok, sedangkan observasi, dokumentasi, dan wawancara sebagai metode pelengkap. Setiap item angket disediakan tiga alternatif jawaban yang sesuai dengan keadaan subyek. Angket ini terdiri atas tiga alternatif jawaban $a, b$ dan c dengan pemberian skor adalah sebagai berikut: untuk jawaban alternatif angket terdiri dari 3 alternatif jawaban yaitu: untuk jawaban ya skornya 3, untuk jawaban kadangkadang skornya 2, sedangkan untuk jawaban tidak pernah skornya 1 (Sugiyono, 2012).

Dalam memperoleh data yang dibutuhkan, perlu teknik atau metode pengumpulan data, sehingga data yang diperoleh dapat dipertanggungjawabkan secara ilmiah. Teknik pengumpulan data yang dipergunakan dalam penelitian ini adalah teknik angket (Quesioner), dokumentasi, observasi, dan wawancara. Dalam buku metodologi penelitian dikemukakan "analisis data merupakan kegiatan setelah data dari seluruh responden atau sumber data lain terkumpul, kegiatan dalam analisis data adalah mengelompokan data berdasarkan variabel dan jenis responden, mentabulasi data berdasarkan dari seluruh variabel, menyajikan data tiap variabel yang diteliti, melakukan "Perhitungan untuk menjawab rumusan masalah, dan melakukan perhitungan menguji hipotesis" (Sugiyono, 2010).

Berdasarkan pendapat di atas, maka peneliti menyimpulkan analisis data adalah merupakan tata cara yang harus digunakan oleh peneliti dalam rangka menganalisis data yang sudah dikumpulkan untuk memperoleh kesimpulan dari hasil penelitian. Dalam penelitian ini, data yang akan diperoleh adalah data yang bersifat kuantitatif (bergejala interval) yang berupa angkaangka. Kemudian langkah-langkah pelaksanaan metode analisis statistik sebagai cara untuk mengolah data untuk 
memperoleh hasil yang sesuai dengan yang diharapkan. Terkait dengan penelitian ini maka metode analisis data yang digunakan adalah analisis data $t$-test.

\section{HASIL PENELITIAN DAN PEMBAHASAN}

Bertitik tolak dari tujuan penelitian yakni, untuk mengatahui ada tidaknya Pengaruh Teknik Biblioterapi Terhadap Sikap Kemandirian Belajar Pada Siswa Kelas VIII SMP Negeri 5 Lembar Kabupaten Lombok Barat Tahun Pelajaran 2018/2019, maka proses pelaksanaan penelitian ini dimulai dari penyebaran angket pre-test yang dilakukan kepada 95 orang siswa yang terdiri dari 4 kelas di antaranya VIII A, VIII B, VIII C dan VIII $\mathrm{D}$ untuk mempermudah berjalannya penelitian ini dan agar proses teknik biblioterapi yang diterapkan dapat berjalan efektif, peneliti hanya mengambil 10 orang siswa yang memiliki tingkat kemandirian yang sangat rendah berdasarkan hasil angket pre-test yang telah disebarkan dan kemudian perlakuan/treatment.

Penelitian ini, data yang diperoleh melalui angket dianalisis dengan menggunakan rumus $t$-test, akan tetapi sebelum data-data tersebut dianalisis menggunakan rumus statistik t-test, peneliti terlebih dahulu melakukan tabulasi atas jawaban angket yang sudah terkumpul. Analisis $t$-test dilakukan untuk mengetahui Pengaruh Teknik Biblioterapi Terhadap Sikap Kemandirian Belajar Pada Siswa Kelas VIII SMP Negeri 5 Lembar Kabupaten Lombok Barat Tahun Pelajaran 2018/2019. Adapun langkah-langkah analisis data sebagai emosi, ekonomi, intelektual, sosial, tingkah laku, dan nilai. Untuk keperluan perhitungan analisis statistik, maka hipotesis alternatif $(\mathrm{Ha})$ yang diajukan pada bab II yang berbunyi: Ada Pengaruh Teknik Biblioterapi Terhadap Sikap Kemandirian Belajar Pada Siswa di SMP Negeri 5 Lembar Kabupaten
Lombok Barat Tahun Pelajaran 2018/2019, maka perlu diubah terlebih dahulu ke dalam hipotesis nol (Ho) sehingga berbunyi: Tidak Ada Pengaruh Teknik Biblioterapi Terhadap Sikap Kemandirian Belajar Pada Siswa di SMP Negeri 5 Lembar Kabupaten Lombok Barat Tahun Pelajaran 2018/2019.

Berdasarkan hasil perhitungan $t$ test yang diperoleh melalui analisis, ternyata nilai $t$ diperoleh $=8.906$ kemudian dikonsultasikan dengan nilai t dalam tabel dengan $\mathrm{db}(\mathrm{N}-1)=10-1=9$ dengan taraf signifikansi $5 \%=2.262$. Dengan demikian nilai ( $\mathrm{t}$-hitung $8.906>\mathrm{t}$ tabel 2.262), maka hipotesis nihil (Ho) ditolak sedangkan hipotesis alternatif (Ha) diterima pada taraf signifikansi 5\% sehingga penelitian ini dinyatakan "Signifikan". Berdasarkan analisis data yang digunakan dalam statistik dengan menggunakan rumus $t$-test $(t$ hitung $8.906>t$ tabel 2.262) maka hipotesis nihil (Ho) ditolak sedangkan hipotesis alternatif (Ha) diterima pada taraf signifikansi 5\% sehingga penelitian ini dinyatakan "Signifikan". Berarti Ada Pengaruh Teknik Biblioterapi Terhadap Sikap Kemandirian Belajar Pada Siswa Kelas VIII SMP Negeri 5 Lembar Kabupaten Lombok Barat Tahun Pelajaran 2018/2019.

Dalam penelitian ini, analisis data dilakukan dua kali yaitu sebelum dan sesudah diberikan treatment biblioterapi. Karena dalam penelitian ini menggunakan one group pre-test post-test design. Dengan demikian, bahwa pelaksanaan teknik biblioterapi mempunyai peranan yang positif dalam membantu sikap kemandirian belajar pada siswa SMP Negeri 5 Lembar Kabupaten Lombok Barat Tahun Pelajaran 2018/2019. Kemandirian biasanya ditandai dengan emosi, tingkah laku, dan nilai. Awalnya penelliti menetapkan sampel 95 orang, kemudian setelah melakukan pre test ternyata yang mencapai nilai kemandirian dalam belajar rendah berjumlah 10 orang 
yang diantaranya laki-laki dan prempuan, selanjutnya peneliti melakukan treatment terhadap 10 orang tersebut, selesai melakukan treatment baru memberikan post test. Hasil dari dari post test menujukkan bahwa tidak ada satu pun siswa yang tidak mandiri. Jadi semua siswa memiliki kemandirian dalam belajar yang tinggi.

Biblioterapi adalah salah satu teknik konseling yang memanfaatkan media buku di dalam bacaan untuk membantu dalam mengubah pikiran, perasaan, perilaku dengan menemukan kesenangan dalam membaca dan melepaskan diri dari distress mental sehingga dapat memotivasi siswa agar mampu mengatasi masalah yang dihadapinya. Pelaksanaan teknik biblioterapi sangat berguna bagi peningkatan sikap siswa untuk membentuk menjadi pribadi yang mandiri karena siswa lebih paham tentang hal-hal yang memang seharusnya dilakukan secara mandiri, tetapi karena lingkungan yang selalu bersifat sudah menyediakan, jadi seorang anak terkadang kurang mau untuk berusaha sendiri. Dengan pelaksanaan teknik biblioterapi ini diharapkan siswa selalu termotivasi untuk belajar, mengubah siswa lebih baik, siswa mempunyai pengetahuan baru dan siswa berkeinginan lebih baik dari sebelumnya.

Biblioterapi merupakan proses pemberian bantuan dengan memanfaatkan buku sebagai media. Metode terapi ini sangat dianjurkan terutama bagi penderita yang sulit mengungkapkan permasalahannya secara verbal.Buku merupakan media yang tepat untuk mendapatkan wawasan, pengetahuan, informasi, dan hiburan. Selain itu, buku dapat menjadi media terapi atau penyembuhan bagi penderita gangguan mental, seperti gangguan kecemasan, trauma, dan stres. Sehubungan dengan metode terapi ini konselor atau guru dapat bersikap penuh simpati dan empati.
Dengan cara ini masalah yang dihadapi konseli dapat berkurang. Karena dengan sikap ini, ia akan memberikan kepercayaan kepada konselor atau guru.

Melalui teknik biblioterapi memanglah sebuah sarana yang tepat dilakukan membantu memecahkan permasalahan yang menggunakan media bahan bacaan untuk mengatasi permasalahan yang dihadapi oleh seseorang yang bermasalah. Dengan demikian teknik biblioterapi diharapkan siswa mempunyai sikap kemandirian belajar yang tinggi sehingga dapat mencapai hasil yang memuaskan serta mampu menyadari kelebihan serta kekurangan yang dimiliki. Berdasarkan dengan hal tersebut, maka peneliti dapat mengambil kesimpulan bahwa apabila teknik biblioterapi mampu diterapkan kepada siswa maka akan membantu konseli dalam memecahkan masalah terutama masalah sikap kemandirian belajar. Artinya apabila teknik biblioterapi dilakukan secara maksimal, maka sikap kemandirian belajar siswa akan meningkat, sehingga siswa lebih mandiri dalam menentukkan masa depannya.

Teknik biblioterapi membantu menegakkan pemikiran rasional, mempromosikan sudut-sudut pandang baru, dan menanamkan minat sosial, dan dapat digunakan dititik manapun selama proses terapi. Buku bisa memungkinkan siswa untuk bisa memiliki instight tentang bagian dirinya yang mungkin belum dikenali. Teknik biblioterapi digunakan untuk menstimulasi diskusi tentang berbagai masalah, mengkomunikasikan nilai-nilai dan sikap-sikap baru, dan menyediakan solusi-solusi realistis untuk berbagai masalah. Teknik biblioterapi memiliki peran untuk membantu siswa agar dapat menemukan kelemahan serta kelebihan yang belum dikenali dalam dirinya dengan menggunakan media bacaan yang sesuai dengan kebutuhannya sehingga dapat mengatasi masalah yang 
berkaitan dengan sikap kemandirian belajarnya.

Sikap kemandirian belajar merupakan suatu usaha yang dilakukan untuk melakukan aktivitas belajar dengan cara melatih diri sendiri tanpa bergantung pada orang lain untuk memperoleh perubahan tingkah laku yang mempunyai kebebasan dalam membuat keputusan serta mampu bertanggung jawab atas tindakannya, sebagai hasil pengalamannya sendiri dalam interaksi dengan lingkungannya. Sikap kemandirian belajar merupakan suatu usaha yang dilakukan mengedalikan emosi untuk melakukan aktivitas belajar dengan cara melatih diri sendiri tanpa bergantung pada orang lain untuk memperoleh perubahan tingkah laku yang mempunyai kebebasan dalam membuat keputusan serta mampu bertanggung jawab atas tindakannya, sebagai hasil pengalamannya sendiri dalam interaksi dengan lingkungannya.

Berdasarkan hasil analisis data yang diperoleh yaitu: ( $\mathrm{t}$ hitung $8.906>\mathrm{t}$ tabel 2.262). Sehingga dari landasan teori yang telah diajukan, jika dibandingkan dengan analisis data yang diperoleh melalui penelitian dengan menggunakan analisis statistik dengan rumus t-test ternyata hipotesis nol (Ho) yang berbunyi: Tidak Ada Pengaruh Teknik Biblioterapi Terhadap Sikap Kemandirian Belajar Pada Siswa Kelas VIII SMP Negeri 5 Lembar Kabupaten Lombok Barat Tahun Pelajaran 2018/2019. ditolak, dan hipotesis alternatif (Ha) yang berbunyi: Ada Pengaruh Teknik Biblioterapi Terhadap Sikap Kemandirian Belajar Pada Siswa Kelas VIII SMP Negeri 5 Lembar Kabupaten Lombok Barat Tahun Pelajaran 2018/2019 diterima. Dengan demikian, bahwa pelaksanaan teknik biblioterapi dengan mempunyai peranan yang positif dalam sikap kemandirian belajar pada siswa SMP Negeri 5 Lembar Kabupaten Lombok Barat Tahun Pelajaran 2018/2019, dengan kata lain semakin intensif pelaksanaan teknik biblioterapi di sekolah, maka semakin meningkat sikap kemandirian belajar siswa.

\section{SIMPULAN DAN SARAN}

Berdasarkan hasil analisis data dan pembahasan bab IV maka dapat di simpulkan bahwa: Ada Pengaruh Teknik Biblioterapi Terhadap Sikap Kemandirian Belajar Pada Siswa Kelas VIII SMP Negeri 5 Lembar Kabupaten Lombok Barat Tahun Pelajaran 2018/2019. Hal ini dapat dilihat dari hasil penelitian yaitu: $(\mathrm{t}$ hitung $8.906>\mathrm{t}$ tabel 2.262) maka hipotesis nihil (Ho) ditolak sedangkan hipotesis alternatif (Ha) diterima pada taraf signifikansi $5 \%$ sehingga penelitian ini dinyatakan "Signifikan".

Berdasarkan simpulan di atas, peneliti sarankan kepada: Bagi kepala sekolah, hasil penelitian diharapkan agar informasi yang diperoleh dalam penelitian ini dapat berguna bagi kepala sekolah untuk mendorong Guru BK dalam memanfaatkan teknik biblioterapi untuk membantu sikap kemandirian belajar pada siswa. Bagi guru BK, hasil penelitian ini diharapkan sebagai masukan guru BK untuk lebih meningkat kan profesionalisme di dalam memberikan layanan bagi para siswa berkaitan dengan layanan bimbingan dan konseling dengan teknik biblioterapi untuk membantu siswa agar meningkatkan sikap kemandirian belajar. Bagi peneliti lain, hasil penelitian ini diharapkan sebagai bahan kajian bagi peneliti selanjutnya yang berhubungan dengan penelitian ini, sehingga hasilnya akan lebih luas dan mendalam yang belum terungkap dalam penelitian ini.

\section{DAFTAR PUSTAKA \\ Ali \& Asrori. 2011. Psikologi Remaja (Perkembangan Peserta Didik). Jakarta: PT. Bumi Aksara. \\ Aluh Hartati, Hariadi Ahmad dan Andika Rifzar Mandasingi. 2020. Hubungan antara Pengendalian}


Diri dengan Prestasi Siswa SMKN

1 Sumbawa Besar. Realita Jurnal

Bimbingan dan Konseling Vol. 5

No 2 Edisi Oktober 2020. Hal

1051 - 1066. Prodi Bimbingan dan

Konseling Fakultas Ilmu

Pendidikan dan Psikologi

Universitas Pendidikan

Mandalika.

Apriliawati, (2011). Potensi Biblio Therapy:ISSN 2338-4700.

Budiningsih, Asri. 2012. Belajar Dan

Pembelajaran. Jakarta: Rineka Cipta

Desmita. 2016. Psikologi Perkembangan

Peserta Didik. Bandung: PT Remaja Rosdakarya

Eliasa, Eva Imania, 2007. Biblioterapi Sebagai Sebuah Metode Tindakan yang Bermakna. Laporan Hasil Penelitian. Yokyakarta: FIP UNY

Erford, B.T, (2016). 40 Teknik Yang HarusDiketahuiSetiapKonselor (Edisi ke-2). Yogyakarta: PustakaBelajar.

Fatimah, E. 2010. Psikologi Perkembangan Peserta Didik. Bandung: CV Pustaka Setia.

Hariadi Ahmad dan Aluh Hartati. 2016. Panduan Pelatihan Self Advocacy Siswa SMP untuk Konselor Sekolah. LPP Mandala. Mataram

Hariadi Ahmad dan Aluh Hartati. 2016. Penerapan Teknik Structure Learning Approach dalam Meningkatkan Self Advocacy Mahasiswa Prodi BK IKIP Mataram. Realita Jurnal Bimbingan dan Konseling Vol. 1 No 2 Edisi Oktober 2016. Hal 117 - 127. Prodi Bimbingan dan Konseling Fakultas Ilmu Pendidikan IKIP Mataram

Hariadi Ahmad dan Dini Kurnia. 2017. Pengaruh Teknik Biblio Edukasi Terhadap Rasa Rendah Diri Pada Siswa Kelas XI di SMA Negeri 8 Mataram. Realita Jurnal
Bimbingan dan Konseling Vol. 2 No 1 Edisi April 2017. Hal 194 202. Prodi Bimbingan dan Konseling Fakultas Ilmu Pendidikan IKIP Mataram

Hariadi Ahmad, Aluh Hartati, dan Nuraeni. 2018. Penerapan Teknik Structure Learning Approach (SLA) dalam Meningkatkan Kesadaran Empati Diri Siswa Madrasah Aliyah Al Badriyah. Realita Jurnal Bimbingan dan Konseling Vol. 3 No 2 Edisi Oktober 2018. Hal 600 - 605 Prodi Bimbingan dan Konseling Fakultas Ilmu Pendidikan IKIP Mataram.

Hariadi Ahmad, dan Lalu Andry Adifa Maulana. 2019. Pengaruh Teknik Video Edukasi Terhadap Berfikir Positif Siswa SMPN 16 Mataram. Realita Jurnal Bimbingan dan Konseling Vol. 4 No 1 Edisi April 2019. Hal 727 - 741. Prodi Bimbingan dan Konseling Fakultas Ilmu Pendidikan IKIP Mataram.

Hariadi Ahmad, dan Yolana Oktaviani. 2019. Pengaruh Teknik Self Instruction Terhadap Harga Diri Siswa Kelas Kelas XI di SMK Negeri 1 Lingsar Kabupaten Lombok Barat. Realita Jurnal Bimbingan dan Konseling Vol. 4 No 2 Edisi Oktober 2019. Hal 806 - 815. Prodi Bimbingan dan Konseling Fakultas Ilmu Pendidikan IKIP Mataram.

Hasrul dan Hariadi Ahmad. 2021. Mereduksi Prasangka Etnik Siswa dengan Teknik Restructuing Cognitive Suatu Krangka Konseptual. Realita Jurnal Bimbingan dan Konseling Vol. 6 No 1 Edisi April 2021. Hal 1213 1222. Prodi Bimbingan dan Konseling Fakultas Ilmu Pendidikan dan Psikologi 
Universitas Pendidikan Riduwan, (2016). Dasar-

Mandalika.

dasarstatistika.

IKIP Mataram, (2011). Bandung: Alfabeta.

PedomanPembimbingan danPenulisanKaryallmia h. Mataram.

Komsiyah, Indah. 2012. Belajar Dan Pembelajaran.

Yogyakarta: Teras

Margono,

Jakarta: RinekaCipta.

Poerwadarminta, (2003).

Kamus Umum

Bahasa Indonesia.

Jakarta: Balai

Pustaka.

Purwanto, Evanthe, Maret (2015). "Pengaruh Biblioterapi Terhadap Psychological wellbeing Perempuan Lajang”. Jurnal Mahasiswa Universitas Surabaya: Vol 4 No. 1.

Shecman, (Eliasa). (2007).Biblio Therapy As A Method of Meaningful Treatment : ISSN 114 434-438 2007).

Sugiyono, (2016). Metode Penelitian Pendidikan, Pendekatan Kuantitatif, Kualitatif, dan R\&D Jakarta: Alfa Beta.

Sugiyono. (2012). Metode Penelitian Pendidikan (Pendekatan Kuantitatif, Kualitatif, dan $R \& D)$. Bandung: Alfabeta.

Sugiyono. 2010. Metode Penelitian Pendidikan (Pendekatan Kuantitatif, Kualitatif, dan $R \& D)$. Bandung: Alfabeta

Suharsimi, (2006). ProsedurPenelitian. Jakarta: PT Rineka Cipta.

Suharsimi, (2014).Prosedur Penelitian Suatu Pendekatan Praktik. Jakarta: Rineka Cipta. 


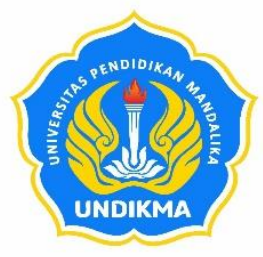

\section{UNIVERSITAS PENDIDIKAN MANDALIKA FAKULTAS ILMU PENDIDIKAN DAN PSIKOLOGI PROGRAM STUDI BIMBINGAN DAN KONSELING Jurnal Realita}

Gedung Dwitiya Lt.3. Jln Pemuda 59A Mataram-NTB 83125 Tlp (0370) 638991 e-mail: realita@undikma.ac.id; web: e-journal.undikma.ac.id

\section{PEDOMAN PENULISAN}

1. Naskah merupakan hasil penelitian, pengembangan atau kajian kepustakaan di bidang pendidikan, pengajaran, pembelajaran, bimbingan dan konseling, dan Psikologi

2. Naskah merupakan tulisan asli penulis dan belum pernah dipublikasikan sebelumnya dalam jurnal ilmiah lain,

3. Naskah dapat ditulis dalam Bahasa Indonesia atau Bahasa Inggris.

4. Penulisan naskah mengikuti ketentuan sebagai berikut:

$\begin{array}{llll}\text { Program } & \text { MS Word } & \text { Margin kiri } & 3.17 \mathrm{~cm} \\ \text { Font } & \text { Times New Roman } & \text { Margin kanan } & 3.17 \mathrm{~cm} \\ \text { Size } & 12 & \text { Margin atas } & 2.54 \mathrm{~cm} \\ \text { Spasi } & 1.0 & \text { Margin bawah } & 2.54 \mathrm{~cm} \\ \text { Ukuran kertas } & \text { A4 } & \text { Maksimum 20 halaman }\end{array}$

5. Naskah ditulis dengan sistematika sebagai berikut: Judul (huruf biasa dan dicetak tebal), nama-nama penulis (tanpa gelar akademis), instansi penulis (program studi, jurusan, universitas), email dan nomor telpon penulis, abstrak, kata kunci, pendahuluan (tanpa sub-judul), metode penelitian (tanpa sub-judul), hasil dan pembahasan, simpulan dan saran (tanpa sub-judul), dan daftar pustaka.

Judul secara ringkas dan jelas menggambarkan isi tulisan dan ditulis dalam huruf kapital. Keterangan tulisan berupa hasil penelitian dari sumber dana tertentu dapat dibuat dalam bentuk catatan kaki. Fotocopy halaman pengesahan laporan penelitian tersebut harus dilampirkan pada draf artikel.

Nama-nama penulis ditulis lengkap tanpa gelar akademis.

Alamat instansi penulis ditulis lengkap berupa nama sekolah atau program studi, nama jurusan dan nama perguruan tinggi. Penulis yang tidak berafiliasi pada sekolah atau perguruan tinggi dapat menyertakan alamat surat elektronik dan nomor telpon.

Abstrak ditulis dalam 2 (dua) bahasa: Bahasa Inggris dan Bahasa Indonesia. Naskah berbahasa Inggris didahului abstrak berbahasa Indonesia. Naskah berbahasa Indonesia didahului abstrak berbahasa Inggris. Panjang abstrak tidak lebih dari 200 kata. Jika diperlukan, tim redaksi dapat menyediakan bantuan penerjemahan abstrak kedalam bahasa Inggris.

Kata kunci (key words) dalam bahasa yang sesuai dengan bahasa yang dipergunakan dalam naskah tulisan dan berisi 3-5 kata yang benar-benar dipergunakan dalam naskah tulisan.

Daftar Pustaka ditulis dengan berpedoman pada Pedoman Penulisan Karya Ilmiah Universitas Pendidikan Mandalika. 


\begin{tabular}{|c|c|c|c|c|c|}
\hline & & & & \\
JURNAL & VOLUME & NOMOR & EDISI & HALAMAN & P ISSN : 2503 - 1708 \\
REALITA & 6 & 2 & Oktober 2021 & $1326-1430$ & E ISSN : 2722 - 7340 \\
& & & & \\
\hline
\end{tabular}

Alamat Qedaksi:

Program Studi Bimbingan dan Konseling Fakultas Ilmu Pendidikan dan Psikologi

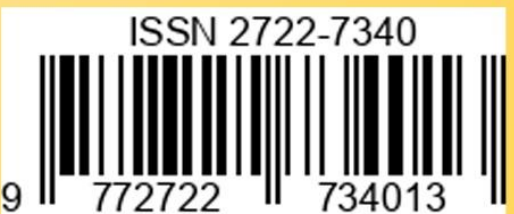

Universitas Pendidikan Mandalika

Gedung Dwitiya, Lt. 3 Jalan Pemuda No. 59A Mataram Telp. (0370) 638991

Email : realita@undikma.ac.id

Web : e-journal.undikma.ac.id

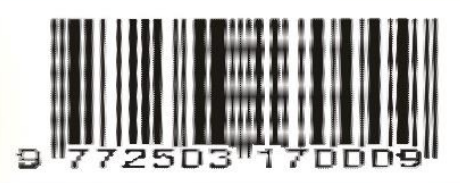

